\title{
Assessment of Food Safety Knowledge and Hygienic Practices among Street
}

\section{Food Vendors in Alexandria}

\author{
Mohamed Abd El-Raouf Koraish, Assistant Professor \\ Nutrition Department, Faculty of Agriculture, Damanhour University
}

\author{
Reem Bassiouny El Lassy, Lecturer \\ Community Health Nursing Department, Faculty of Nursing, Damanhour University
}

\begin{abstract}
The street food industry plays an important role in meeting the food demands of the urban dwellers in developing countries. Foods are often prepared under unsanitary conditions and stored for long periods in unsuitable conditions before selling. Objective: The aim of this study was to assess food safety knowledge and hygienic practices among street food vendors in Alexandria. Setting: The study was carried out in Alexandria City, which composed of eight zones; out of them three zones were randomly selected (El-Montaza, East and El-Gomrok Zones). Subjects: The total sample was 100 street food vendors. Tools: Tool I: Street vendor's personal, vending data and food vending knowledge structured interview schedule and Tool II: Vending environment and hygienic practices of street vendors by using observation checklist. Results: The majority (91.0\%) of street vendors were males and their mean age was $30.48 \pm 8.5$ years. Less than half (41.0\%) of them were mobile street vendors, working for more than 5 years. Food poisoning and dysentery were the most prevalent type of food borne diseases identified by street vendors and $86.0 \%$ of them acquired their knowledge about food vending by experience. Conclusion: The present study concluded that the majority of food vendors acquired the knowledge of food preparation by self-teaching and some of their knowledge could not be translated to practice due to absence of basic facilities. Recommendations: The study recommended that food vendors should be adequately educated on the relation between food and disease transmission as well as on principles of personal hygiene and safety food practices. Also, the routine medical examination of food handlers must be carried out by health office for regulating safe street food handling, preparation and vending.
\end{abstract}

Keywords: Food safety knowledge, hygienic practices, street-vended foods.

\section{Introduction}

Street-vended foods are defined as those foods prepared on the street or at home and ready to eat, they are consumed on the street without further preparation ${ }^{(1,2)}$. They include foods such as meat, fish, fruits, vegetables, grains, cereals, frozen product and beverages prepared and/or sold by vendors; especially on streets and public places $^{(3,4)}$. They may be consumed where it was purchased or can be taken away and eaten elsewhere ${ }^{(5)}$.
In developing countries, drinks, meals and snacks sold by street food vendors are widely consumed by millions of people. There are increased interests worldwide on the importance of street food as part of a general concern for food security and health. The incidence of food-borne diseases is rising in developing countries, as well as in the developed world ${ }^{(2)}$.Each year, millions of people worldwide suffer from food-borne diseases as paratyphoid or typhoid fever, a systemic febrile illness caused by Salmonella typhi and S. paratyphi $\mathrm{A}, \mathrm{B}$ or $\mathrm{C}$. Illness resulting from the 
consumption of contaminated food has become one of the most widespread public health problems in contemporary society $^{(6,7)}$.

There is a noticeable increase in number of food vendors as a result of dwindling economy, unemployment and the rapidly growing and changing food demands by the urban dwellers needing cheaper food in the face of a harsh economy ${ }^{(8)}$. There are three main categories of street food vendors, namely 'mobile' vendors (hawkers move around carrying their specialties in pots, baskets and jugs). Those vendors on bikes, motorcycles or vans sell anything from pizza to goat's milk, 'semi-mobile' vendors, who may be move from one place to another and operate from carts, setting up at different places throughout the day or season, at predetermined times and locations. In addition, 'stationary' vendors who sell their food at the same site each day or fixed stalls located outdoors, easily accessible from the street with low-cost seating facilities ${ }^{(4)}$.

It is recognized that street food vendors are often poor, uneducated and lack in knowledge and practice of safe food handling. Consequently, they are perceived to be a major public health risk to the community $^{(4)}$.

Food handlers play an important role in ensuring food safety throughout the chain of production, processing, storage and preparation $^{(9,10)}$. Hence, mishandling and disregard of hygienic measures on the part of the food vendors may enable pathogenic bacteria to come into contact with and in some cases survive and multiply in sufficient numbers to cause illness among consumers $^{(11)}$.

In spite of numerous advantages offered by street foods, there is also several health hazards associated with this sector of the economy. Multiple lines of evidence reveal that foods exposed for sale on the roadsides may become contaminated either by spoilage or pathogenic micro-organisms.
Evidently, street vended foods have shown epidemiological links with illness. FAO (1997) further stipulates that street foods raise concern with respect to their potential for serious food poisoning outbreaks ${ }^{(12,13)}$.

To sum up, street foods and their tremendous unlimited and unregulated growth has placed a severe strain on city resources, such as water, sewage systems and interference with the city plans through congestion and littering adversely affecting daily life ${ }^{(8,13)}$.

\section{Aim of the Study}

This study was conducted to assess of food safety knowledge and hygienic practices among street food vendors in Alexandria.

\section{Research Questions:}

The research questions underpinning this study were:

1. What is the food safety knowledge among street food vendors in Alexandria?

2. What are the hygienic practices among street food vendors in Alexandria?

\section{Materials and Method}

\section{Materials}

Design: A descriptive survey study.

Setting: The study was carried out in Alexandria City, which composed of eight zones; out of them three zones were randomly selected (El-Montaza, East and El-Gomrok Zones).

Subjects: No available records or data base for the total population of the street food vendors in each of the previously randomly selected zones, therefore, the researchers had to use haphazard sample selection. Accordingly, those street vendors available in the main streets, train stations, around schools and hospitals were included in the 
study. The required sample size was 100 (30 from El-Montaza, 40 from East and 30 from El-Gomrok Zones) with $15 \%$ relative precision and $95 \%$ confidence level. Those street food vendors who were unwilling to participate were excluded from the study.

Tools: Two tools were used by the researchers in order to collect the necessary information from street food vendors.

Tool I: Street vendor's personal, vending data and food vending knowledge structured interview schedule

\section{Part I:}

- Socio-demographic information such as age, marital status, educational level, main occupation, place of residence.

\section{Part II:}

- Type of vendor, duration of being street vendor.

- Types of foods sold.

\section{Part III:}

- Knowledge of food vendors about food borne diseases, mode of transmission, sources of food contamination, causes of food poisoning and principles of food safety.

- Sources of food vending knowledge.

Tool II: Vending environment and hygienic practices of street vendors by using observation checklist

- Characteristics of surrounding environment such as cleanliness of floor surface, presence of insect, food exposed to vehicle exhaust and/or directly to sunlight.

- Characteristics of place and location of outlet and the nature of the vending sites

- Food vendors practices such as dealing with rubbish, waste disposal, preparation and handling of food and its' storage.

- Personal and food hygienic practices such as status of nails and cleanliness of the hands, smoking and taking care not to cough over food, wearing jewelry, and handling of food and money without wearing gloves and washing hands in between.

\section{Method}

1- Tools of data collection were developed by the researchers and tested for its content validity and relevance by a jury consisted of 3 academic staff in community health Nursing at Mansoura, and Damanhour University. The necessary modifications were performed.

2- The pilot study was conducted on 10 of street-food vendors in El Beheira Governorate in order to ascertain tools' clarity and feasibility. Test of reliability was conducted using Cronbach's Alpha (0.788).

3- Each food vendor was interviewed during work to collect the necessary information.

4- Each interview and observation took 45-60 minutes. Participants' observation done in average of two to three selling process.

Data was collected during eight months starting in May 2013 until January 2014.

\section{Ethical considerations:}

All participants were informed about the purpose of the study and oral consent was obtained prior to conducting the study. Confidentiality of vendors' responses were guaranteed during the study. 


\section{Statistical Analysis}

- Data was analyzed using PC with Statistical Package for Social Sciences (SPSS) version 16.0.

- Statistical significance level was set at $5 \%(\mathrm{p} \leq 0.05)$.

- The following statistical measures were used:

\section{Descriptive statistics:}

Number and percentage: Used for describing and summarizing qualitative data.

Arithmetic means and Standard deviation (SD): used as measures of central tendency and dispersion respectively to summarize quantitative data.

Fisher exact test and Monte Carlo test: used when expected frequency $<5$ exceeding $20 \%$ of cells.

\section{- Scoring system}

\section{Section 1: Street-food vendors'} practices:

This section of the questionnaire includes 28 items of food handling practices. The items were scoring as following: A score "1" was given to correct practice item. While, score "0" was given to wrong or inaccurate. The total practice score was obtained for each vendor (0-28). Percent total practice score was calculated as follows; poor practice <14 (less than 50\%), fair practice 14-<21 (50$<75 \%)$ and good practice $\geq 21$ ( $\geq 75 \%)$

Section 2: Knowledge of food vendors about food borne diseases, mode of transmission, sources of food contamination, and causes of food poisoning and principles of food safety:

This section of the questionnaire consists of 5 items. A scoring system for assessing the vendor's knowledge regarding food safety;

The correct answers were predetermined according to the literature. A score of (2) was given to the correct complete answer, a score of (1) for correct but incomplete answer and a score of $(0)$ for the wrong or missed answers. The total knowledge score was obtained for each vendor $(0-10)$.

Percent total knowledge score was calculated as follows;

$\square$ Poor knowledge $<5(<50 \%)$

$\square$ Satisfactory $5-<7.5(50-<75 \%)$

$\square$ Good $\geq 7.5(\geq 75 \%)$

\section{- Graphical presentation:}

Graphs were done for data visualization by using Microsoft Excel.

\section{Results}

Regarding characteristics of the studied sample, table (1) reveals that their mean age was $30.48 \pm 8.5$ years and ranged from 20 to 57 years. More than one third $(36 \%)$ of the vendors were in the age groups 20 to less than 30 years, followed by 30 to less than 40 years $(27.0 \%)$ and young vendors (less than 20 years) amounted to $18.0 \%$.The majority $(91.0 \%)$ of the vendors were males and only $9 \%$ were females. Half of them were illiterate and/or could just read and writes but $28.0 \%$ had a secondary education or above middle education. In addition, more than half of them $(53.0 \%)$ were rural residence.

Table (2) shows that the majority of the vendors $(80.0 \%)$ indicated that their main occupation was street food vending. Fifty nine percent of the respondents had been in the food handing trade for less than five years. Only $29.0 \%$ of vendors mentioned that they were street vendor from 5 to less than 10 years. More than half $(59.0 \%)$ of the vendors were selling at stationary stalls at the streets, while the rest $(41.0 \%)$ were mobile vendors.

Regarding the kinds of foods that vendors sale, it was found that half of the vendors were selling beans \& falafel/ eggs, 
hot-dogs/ burgers/meat, chicken, fish, etc. While beverages (hot-drinks/ juices/soft drinks/canes) were also popular street food which sold by $28.0 \%$ of the vendors. It has to be noticed that $68 \%$ of them had no license

Table (3) portrays the characteristics of food vending places and location of outlet. The vending sites were spread between fixed booth $(59.0 \%)$, mobile trucks $(25.0 \%)$ or portable trays/containers $(16.0 \%)$. The areas in which the vendors processed their businesses were set out in the same table, where the majorities interviewed near transportation and around residential areas (35.0 \% \& 30\% respectively) and in commercial areas were $11.0 \%$. It was observed that $6.0 \%$ of the vendors had a garbage dump within less than five meters of their outlets, while $58.0 \%$ must walk for more than 100 meters to the nearest garbage dump.

Regarding water facilities, more than half $(53.0 \%)$ of those who had access to water, were using tap water which located at mosques. Another $30.0 \%$ used tap water of toilets belonging to the public areas.

Figure (1) reveals the nature of the vending sites as well as the state of the floor surface of the outlets where the street food vendors rendering their business. Most of the vendors $(80.0 \%)$ processed their businesses from outlets with dusty floor which could be easily clean (49.0\%). However, the majority of vendors' foods were exposed directly to sunlight and vehicle exhaust.

Table (4) reflects vendors' practices in dealing with rubbish and waste water disposal. More than one third (38\%) of food vendors thrown their refuse in municipal bins, $40.0 \%$ took it to the garbage dump and more than one fifth $(21.0 \%)$ leaved it behind wrapped using plastic bags. The same table presents that more than one third $(37.0 \%)$ of the vendors thrown waste water into the drainage system. However, $63.0 \%$ of them thrown it on the road.
Regarding methods of dealing with leftovers food, most of the vendors $(73.0 \%)$ reported that they throw leftover away or resale at next day. Less than fifth $(19.0 \%)$ of the vendors take leftovers back home. It was found that $30.0 \%$ of the vendors reported using oil when cooking and use oil when frying foods. Of those sold frying foods, more than two thirds $(66.7 \%)$ changed frying oil monthly.

Table (5) shows the number of vendors who had access to toilet facilities at their business outlets. The majority of vendors $(94.0 \%)$ reported availability and accessibility to toilets; only $(6 \%)$ did not have toilet facilities. It was found that more than one third of them used the public toilets $(76.6 \%)$, mosque $(25.5 \%)$ and train rails' toilet $(11.7 \%)$. The majority of the vendors washed their hands after visiting the toilet with running water $(81.0 \%)$.

Table (6) demonstrates street food vendors' practices in preparation of foods as bean or foul \& falafel/ cooked vegetable/ soup, sauces, meat, chicken, fish, etc. It was observed that surfaces used by vendors to prepare street food were from wood, plastic, metal, etc. Wood surfaces were used by two-thirds $(66 \%)$ of the vendors, $17.0 \%$ for aluminum surfaces and $12.0 \%$ used plastic surfaces to prepare their stuff. Two-thirds $(68 \%)$ of the street food vendors prepared food that they sold at their stalls. It was found that the preparation surfaces were unclean in $40.0 \%$ of them. Moreover, seventy percent of them washed the needed food before cooking it.

Table (7) presents food-handling practices and types of materials used in serving foods. More than half of the vendors serving foods using aluminum plates compared to $42.0 \%$ using newspapers for wrapping the served foods. In addition, less than half of them used a cooler box or refrigerator for food storage, $31.0 \%$ stored openly in the stalls.

Table (8) portrays the street vendors' practices during handling of utensils. Wash 
of cooking utensils only at the end of the day was mentioned by the majority $(78.0 \%)$ of the vendors, $18.0 \%$ washed their utensils with the preparation of a new batch of prepared food. While, less than two thirds $(63.0 \%)$ of them washed their utensils at bucket, $53.0 \%$ was used cold water and detergent to wash their utensils and 58\% changed the water severally/or when becomes viscous and sticky.

Concerning vendors' total practices' scores, table (8) presents that more than two thirds $(67.0 \%)$ of street food vendors had fair practice scores $(50-<75 \%)$. However, $23.0 \%$ of them had poor practice level $(<50 \%)$. The total mean scores of practice were $7.9 \pm 1.9$.

Personal hygienic practices of the street food vendors are projected in table (9). More than three quarters $(77.0 \%)$ of the vendors wore clean clothes. However, $80.0 \%$ did not wear apron while cooking or serving food while $16.0 \%$ wore hair covering. The majority of them $(86.0 \%)$ handled foods without gloves and $42.0 \%$ wore jewelry while handling food. It was observed that $93.0 \%$ were handling money while serving food and $26.0 \%$ of the vendors blew air into polythene bag before use it. Very few (14\%) of the vendors were not aware that it was necessary to wash their hands even when handkerchief is used for covering mouth when cough.

Results on the knowledge exhibited by the food vendors about food safety and food borne diseases were presented in table (10); food poisoning and dysentery were the most prevalent types of food borne diseases identified, followed by Typhoid and Hepatitis A. Insects and dirt were mentioned by exactly half of the vendors as food contaminants and poor hygienic practice was the most common (61.0\%) reported mode of transmission, while all vendors stated stomach pain as the main prevailing symptom of food borne illness. Knowledge for food vending was acquired by experience in $(86 \%)$ of the street vendors. Only $(1.0 \%)$ of them admitted that he acquired his knowledge from formal training in food handling, while $23.0 \%$ acquired their knowledge by observation or taught by their parents.

Concerning the total scores of vendors' knowledge about food borne diseases, mode of transmission, sources of food contamination, causes of food poisoning and principles of food safety; table (10) portrays that the majority $(92.0 \%)$ of street food vendors had poor knowledge scores (< $50 \%)$. However $8 \%$ of them had satisfactory level $(50-<75 \%)$. The total mean scores of their knowledge was $3.7 \pm 1.3$.

Table (11) shows the relation between total knowledge scores and sociodemographic characteristics of street food vendors. No significant were observed between total knowledge scores and sociodemographic characteristics of street vendors such as age, education, place of residence and type of vendor.

Table (12) conveys the relation between total practices' scores of street food vendors and their socio-demographic characteristics. A significant relation was observed between vendors' practice scores and their age, place of residence and types of vendor $(\mathrm{MCP}=$ $0.035,0.001$ and 0.001 respectively).No significant relation between vendors' educational level and duration of being street vendors.

Table (13) illustrates the relation between street food vendors' hygienic practices and sources of water supply. A significant relation was observed between vendors' sources of water supply cleanliness of food preparation surface, wash food before cooking and dealing with waste water $(\mathrm{MCP}=0.050,0.019$ and 0.050 respectively).

Table (14) conveys the relation between total knowledge scores and personal hygienic practices of street food vendors. A significant relation was observed only between total knowledge scores of vendors and hair covering and wear apron ( $\mathrm{FEP}=0.006$ and 0.027 respectively). 
Results of the relation between total practices' scores and personal hygienic practices of street food vendors were presented in table (15); significant relation were found between total practices' scores and some items of their personal hygienic practices (hair covering, handle foods without gloves, talking while working with food and dry sweat in a way that does not contaminate food) which were $(\mathrm{MCP}=0.001,0.013,0.006$ and 0.050 respectively).

\section{Discussion}

In many cities and towns in developing countries, street food vending is a great source of employment and contributes significantly to households incomes ${ }^{(14,15)}$. The present study reveals sociodemographic data of street food vendors, it shows that the majority of them were males, and only 9 percent were females. Also, more than one third of them belonged to age category of 20- 30 years (table 1). This is in line with the situation in Guwahati city (India), where Choudhury et al. at $2011^{(14)}$ recorded $88 \%$ males in this activity. Contrary to other studies, where the street food enterprises in Brazil, Gauteng in South Africa and Bangkok in Thailand is dominated by females ${ }^{(16)}$. In respect to educational levels, more than half of vendors had primary education and below. More than one fourth of them had secondary or/and above middle education. Eighty percent of the vendors had food vending as their main occupation (table 2). Lower educational levels of street food vendors have been linked to poor hygiene practices leading to food contamination during handling, storage and food preparation $^{(17)}$.

One of the common ways of regulating street vended food in the developing countries is through medical examination of food vendors, where the majority of the food vendors had no health certificates ${ }^{(18)}$. This is in line with results of the present study (table 2). So, it is important that laws and regulations should be enforced in order to check the standards of food safety.

Personal hygiene is important because human beings are the largest contamination sources of food. Handling with bare hands may lead to cross contamination and introduction of microbes to safe food ${ }^{(19)}$.Regarding the observed personal hygienic practices of street food vendors in the present study, it was noticed that more than three quarters of them did not wearing aprons, handled food without wear gloves, and didn't use hair covering. In addition, the majority of food vendors handled money during serving food and more than one third of them wore jewelry while serving food and blew air into polythene bag before use it (table 9). Poor hygienic practices of street food vendors may be due to lack of awareness about relation between personal hygienic practices during handling foods and food safety. This is in agreement with findings of Muinde et al in Niarobi where they found that $81.3 \%$ of the vendors did not use aprons, $60 \%$ handled food with their bare hands and $65 \%$ had their hair not covered. All their vendors handled money while serving food and only $10 \%$ of them wore jewelry ${ }^{(19)}$. Moreover, these findings are in accord with the study in Brazilat 2005 ${ }^{(20)}$.So, it has become necessary that systems should be established to ensure that food handlers remain aware of all procedures necessary to maintain the safety and suitability of food.

The study also apparently shows that street food vendors considered wearing hair covering and aprons only are important for safer street food vending (table 14). These results are contrary to the study done in Ghana $(2011)^{(18)}$.

Street foods are sources of nutrition for many low-income groups. Nevertheless, these foods could be main vehicle for transmission of severe and fatal diseases that could be life threatening. Contamination of these foods could result from pre or post cooking contamination 
from the food handlers. Participants of the present study were to some extent have information that several food-borne illnesses result from unsound foods. This can explain that more than half of them wash utensils with cold water and detergent (table 8). This similar to Behrens et al. (2010), who reported that in Brazil, various disinfecting agents were used by street food vendors in order to eliminate contaminants $^{(21)}$.

The hands are the most important vehicles for the transfer of organisms from faeces, nose, skin, or other sites to food $^{(22)}$. In the present study, clean water supply and hand washing or toilet facilities are not available to food street vendors. The majority of the participants reported that they did not have access to running water all the time (table 5). This is in agreement with the findings of Bryanet al. (1988) and Abdalla et al. (2009) ${ }^{(22)}$. All these findings are in disagreement with requirements for effective hand washing of $\mathrm{WHO}^{(22)}$.

Sources of water supply have been linked to poor hygienic practices of street food vendors. Throughout cleanliness of preparation surface, washing food before cooking and dealing with waste which may lead to vending of unsafe food and food contamination (table 13).

Street food vendors are often unlicensed, untrained in food safety, food hygiene and sanitation, and work under crude unsanitary conditions. In Malaysia, recommended training of food vendors through the mass media as the most cost effective use of resources. Also integrated health education approaches on a "stall to stall" basis were more effective than giving it on a large group basis. Appropriate codes of practice and guidelines on safe food handling should be established and introduced into the school curriculum ${ }^{(23)}$. In the present study knowledge of food vending was acquired by self-teaching by trial and error in the majority of the street vendors. Only small percent of them admitted to formal training in food handling and vending while about one fourth acquired their knowledge by observation or taught by their parents. (table10)These results are contrary to Muinde and Kuria study in Nairobi $(2005)^{(19)}$, which showed that vendors lacked training on food preparation and reported that most (61.0\%) of the vendors acquired cooking skills from observation, $33.0 \%$ were taught by their parents while $6.3 \%$ gained the skills by trial and error (self-taught). Omemu et al (2008) noted in their study at Nigeria that few vendors $(12.0 \%)$ acquired the knowledge of food preparation by formal training ${ }^{(24,25)}$.

Hygiene during handling and cooking of street foods is very important. According to FAO, food handlers should have the necessary knowledge and skills to enable them to handle food hygienically. In the present study the majority of participants had poor knowledge scores (table 10). In addition, they reported that they did not have access to running water all the time and collect water at tankers for using later (table 3). This is similar to study done in India ${ }^{(26)}$ as sixty five percent of urban and $39.36 \%$ of the rural food vendors were using tap water for preparing food but they did not have access to running water all the time. They collected water from roadside tap or mobile tankers then stored it for later use in a container. The same water was used for cooking food, washing hands and dishes. Hand washing was found difficult due to lack of running water at the vending site. These results contrary to Martins (2006) who observed otherwise in his study at South Africa ${ }^{(4)}$.

Majority of the vending sites were fixed booth in approximately half of street food vendors and wheelbarrow in one fourth of them which were poorly constructed (table 3). Muinde et al (2005) confirm in their study that these sites do not give proper protection of street foods from dust and smoke from vehicles and they affirm that dust carries many microbes which may be pathogenic if left to settle on prepared 
foods ${ }^{(19)}$. The present study reveals that less than one third of our vendors stored food for serving openly in the stalls while one fourth stored them in the wheelbarrows. One fourth of vendors had leftover for serving to the next day and only half of them have cooler box or refrigerators for storage when there is electric power. An important issue influencing food contamination and contributing to further increase in contamination is food storage temperature. The preparation of food long before its consumption, storage at ambient temperature, inadequate cooling and reheating, contaminated processed food, and undercooking are identified as the key factors that contribute to food poisoning ${ }^{(3)}$.

It was observed that more than three quarters of food vendors washed their utensils once and washed severally during preparation of each batch reported by more than half of vendors (table 8). Majority of them threw the waste water carelessly about around the stalls on the road surface (table 4). It is obvious that a lot of health education is necessary among those street vendors to avoid food related infections, contaminations and hazards ${ }^{(27,28)}$.

It was conveyed in the present study that the poor level of knowledge and its translation to fair level of hygienic practice of surveyed street food vendors may be due to the relation found between vendors' age, place of residence and types of vendor (table 12). These due to the unavailability of hygienic facilities in the place of outlet. Street foods are perceived to be a major public health risk due to lack of basic infrastructure and services, difficulty in controlling the large numbers of street food vending operations because of their diversity, mobility and temporary nature ${ }^{(29)}$.

\section{Conclusion}

Based on the current study results, it can be concluded that, most of food vendors have lack in the availability of basic infrastructures in their working sites. These include supplies of potable water, electricity, and waste disposal services, proper drainage system and public toilets. As regards food vending knowledge, the majority of street food vendors acquired their knowledge by self-teaching. As for hygienic practices, the majority of the vendors did not wear apron while cooking or serving food, handled foods without gloves and the minority were not aware that it was necessary to wash their hands even when handkerchief is used for covering mouth when coughing. It was found that street food vendors' practices were significantly influenced by their age, place of residence and types of vendor. Moreover, personal hygienic practices of street food vendors including hair covering and wear apron were significantly influenced by their knowledge.

\section{Recommendations}

The following recommendations are derived from the current study results:

1. It has become necessary that systems should be enforced to ensure that food handlers remain aware of all procedures necessary to maintain the safety and suitability of food.

2. Food vendors' education is important issue and vendors should be adequately educated on the relation between food and disease transmission as well as on principles of personal hygiene and safety food practices in handling street food.

3. Authority may issue licenses to the street food vendors after they fulfill some of the basic and essential food safety and hygienic measures.

4. The routine medical examination of food handlers must be carried by health officers for regulating safe street food handling, preparation and vending.

5. Periodic training of the vendors regarding safe food handling may help in improving the situation. 
Table (1): Distribution of street food vendors according to their socio-demographic characteristics.

\begin{tabular}{|l|c|c|}
\hline \multirow{2}{*}{ Socio-demographic characteristics } & \multicolumn{2}{|c|}{ Street food vendors (n=100) } \\
\cline { 2 - 3 } & No & \% \\
\hline Age (in years) & 18 & 18.0 \\
<20 & 36 & 36.0 \\
$20-$ & 27 & 27.0 \\
$30-$ & 19 & 19.0 \\
$40+$ & \multicolumn{2}{|c|}{$30.48 \pm 8.5$} \\
\hline Mean \pm SD & & \\
\hline \hline Gender: & 91 & 91.0 \\
Male & 9 & 9.0 \\
Female & & \\
Level of education & 50 & 50.0 \\
Illiterate \& or read and write & 7 & 7.0 \\
Primary education & 15 & 15.0 \\
Preparatory education & 18 & 18.0 \\
Secondary education & 10 & 10.0 \\
Above-middle education & & \\
Marital status & 35 & 35.0 \\
Single & 56 & 56.0 \\
Married & 6 & 6.0 \\
Widow & 3 & 3.0 \\
Divorced & & \\
Place of residence & 53 & 53.0 \\
Rural & 47 & 47.0 \\
Urban & & \\
\hline
\end{tabular}


Table (2): Distribution of the studied sample according to characteristics of their present occupation as food street vendors.

\begin{tabular}{|c|c|c|}
\hline \multirow[t]{2}{*}{ Items } & \multicolumn{2}{|c|}{$\begin{array}{l}\text { Street food vendors } \\
\qquad(\mathrm{n}=100)\end{array}$} \\
\hline & No & $\%$ \\
\hline \multicolumn{3}{|l|}{ The main occupation } \\
\hline Street vendor & 80 & 80.0 \\
\hline Fisher man & 2 & 2.0 \\
\hline Worker (factory, school, etc.) & 17 & 17.0 \\
\hline Employee & 1 & 1.0 \\
\hline \multicolumn{3}{|l|}{ Duration of being street vendor } \\
\hline$<5$ years & 59 & 59.0 \\
\hline $5-$ & 29 & 29.0 \\
\hline $10-$ & 10 & 10.0 \\
\hline $20+$ & 2 & 2.0 \\
\hline Mean \pm SD & \multicolumn{2}{|c|}{$6.86 \pm 0.99$} \\
\hline $\begin{array}{c}\text { Type of vendor } \\
\text { Stationary } \\
\text { Mobile }\end{array}$ & $\begin{array}{l}59 \\
41\end{array}$ & $\begin{array}{l}59.0 \\
41.0\end{array}$ \\
\hline \multicolumn{3}{|l|}{ Licensed } \\
\hline Yes & 32 & 32.0 \\
\hline No & 68 & 68.0 \\
\hline Types of foods sold & \multicolumn{2}{|c|}{$\mathrm{n}=100$} \\
\hline $\begin{array}{l}\text { 1. Beverages } \\
\text { (Hot drinks/ Soft drinks or juices/canes and bottled drink) } \\
\text { 2. Food types }\end{array}$ & 28 & 28.0 \\
\hline $\begin{array}{l}\text { (Snacks/ Bean or foul \& falafel/ Cooked vegetable/ soup, sauces, } \\
\text { meat, chicken, fish, etc.) }\end{array}$ & 50 & 50.0 \\
\hline $\begin{array}{l}\text { 3. Food for entertaining } \\
\text { (Lupine/ Roasted groundnut/Peanuts/hazel/Nuts) }\end{array}$ & 22 & 22.0 \\
\hline
\end{tabular}


Table (3): Distribution of the studied sample according to characteristics of place and location of outlet.

\begin{tabular}{|c|c|c|}
\hline \multirow[t]{2}{*}{ Items } & \multicolumn{2}{|c|}{$\begin{array}{c}\text { Street food vendors } \\
(\mathrm{n}=\mathbf{1 0 0})\end{array}$} \\
\hline & No & $\%$ \\
\hline \multicolumn{3}{|l|}{ Type of vending site } \\
\hline Fixed booth & 59 & 59.0 \\
\hline Mobile truck /Wheelbarrow & 25 & 25.0 \\
\hline Portable trays/ Container & 16 & 16.0 \\
\hline \multicolumn{3}{|l|}{ Place and location of outlet } \\
\hline Around residential area & 30 & 30.0 \\
\hline At transportation area & 35 & 35.0 \\
\hline Recreational area (beach, garden) & 13 & 13.0 \\
\hline Commercial area & 11 & 11.0 \\
\hline In front of school & 7 & 7.0 \\
\hline In front of hospital & 4 & 4.0 \\
\hline \multicolumn{3}{|l|}{ Distance of street food outlet from the garbage dump } \\
\hline$<50$ meters & 6 & 6.0 \\
\hline $50-$ & 36 & 36.0 \\
\hline $100+$ & 58 & 58.0 \\
\hline Presence of stray cats, rodents and insects at places of selling & 60 & 60.0 \\
\hline \multicolumn{3}{|l|}{ Source of water supply\# } \\
\hline Bring water from home & 25 & 25.0 \\
\hline Use of private property & 10 & 10.0 \\
\hline Mosques & 53 & 53.0 \\
\hline Public areas & 30 & 30.0 \\
\hline Presence of water container/tanksfor water storage & 77 & 77.0 \\
\hline
\end{tabular}

\# Multiple responses were given 


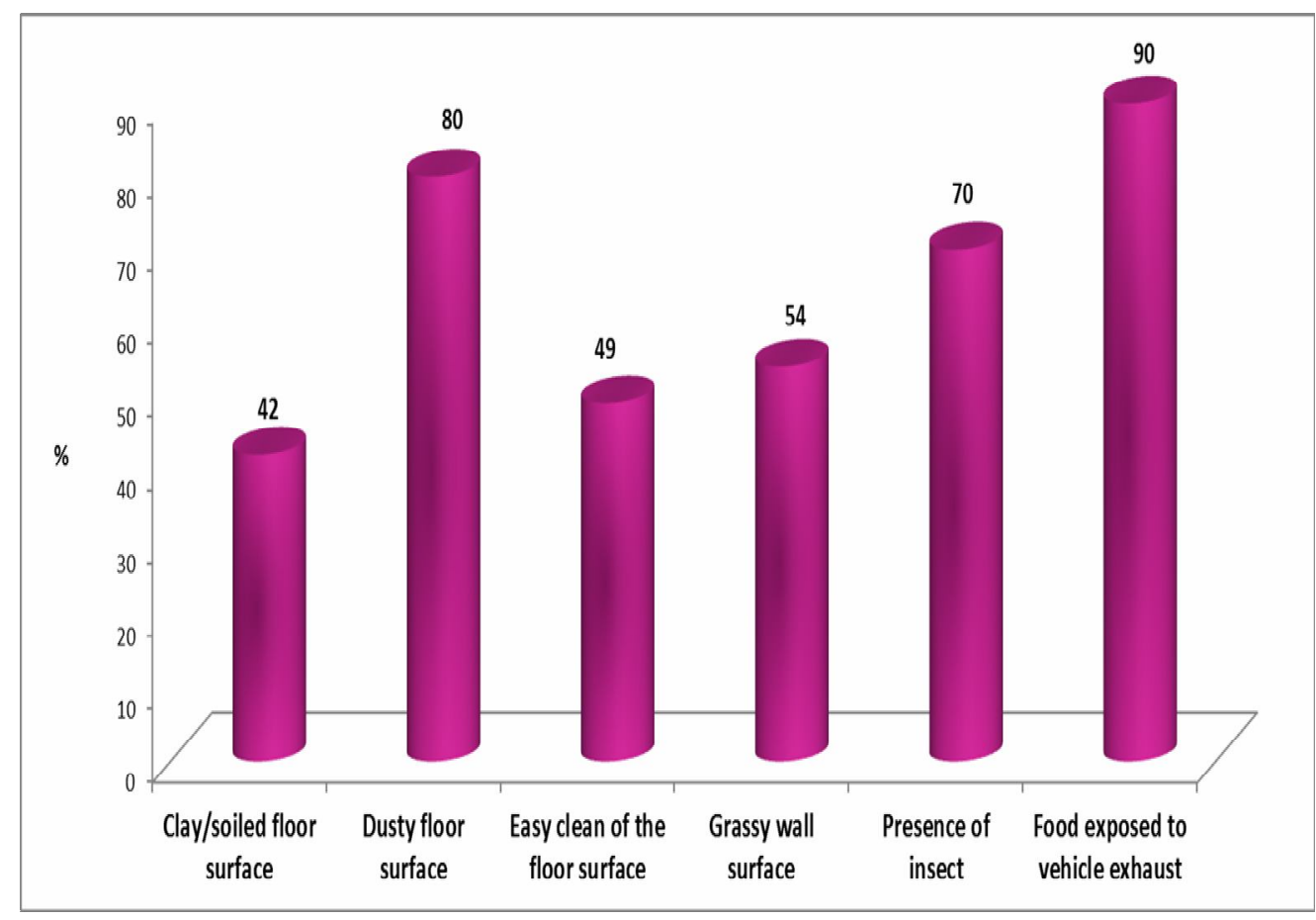

Figure (1): The nature of the vending sites

Table (4): Distribution of the studied sample according to their practices in dealing with rubbish and waste water disposal.

\begin{tabular}{|c|c|c|}
\hline \multirow[t]{2}{*}{ Items } & \multicolumn{2}{|c|}{$\begin{array}{c}\text { Street food vendors } \\
(n=100)\end{array}$} \\
\hline & No & $\%$ \\
\hline $\begin{array}{l}\text { Dealing with rubbish disposal\# } \\
\text { Take to the garbage dump } \\
\text { Throw in municipal bins } \\
\text { Leave behind unwrapped } \\
\text { Leave behind wrapped using plastic bags }\end{array}$ & $\begin{array}{l}40 \\
38 \\
16 \\
21\end{array}$ & $\begin{array}{l}40.0 \\
38.0 \\
16.0 \\
21.0\end{array}$ \\
\hline \begin{tabular}{|l|} 
Frequency of rubbish disposal \\
Daily \\
More than twice weekly \\
\end{tabular} & $\begin{array}{c}94 \\
6 \\
\end{array}$ & $\begin{array}{c}94.0 \\
6.0 \\
\end{array}$ \\
\hline \begin{tabular}{|l|} 
Dealing with waste water \\
Throw on the road surface \\
Throw into the drainage system
\end{tabular} & $\begin{array}{l}63 \\
37 \\
\end{array}$ & $\begin{array}{l}63.0 \\
37.0\end{array}$ \\
\hline
\end{tabular}

\# Multiple responses were given 
Table (5): Distribution of the studied sample according to toilet facilities.

\begin{tabular}{||l|c|c||}
\hline \multicolumn{1}{||}{ Items } & \multicolumn{2}{|c|}{$\begin{array}{c}\text { Street food vendors } \\
\text { (n=100) }\end{array}$} \\
\cline { 2 - 3 } & $\mathbf{N o}$ & \% \\
\hline Access/Use of toilet & 94 & 94.0 \\
Yes & 6 & 6.0 \\
No & & \\
Place of toilet used \# & 11 & 11.7 \\
Train rail & 72 & 76.6 \\
Public toilets/ parks & 24 & 25.5 \\
Mosque & 6 & 6.4 \\
On street & & \\
Hands washing after toilets & 81 & 81.0 \\
Running water & 19 & 19.0 \\
Separate container/tanks & & \\
\hline
\end{tabular}

\# Multiple responses were given

Table (6): Distribution of the studied sample according to food-preparation practices.

\begin{tabular}{|c|c|c|}
\hline \multirow[t]{2}{*}{ Items } & \multicolumn{2}{|c|}{$\begin{array}{c}\text { Street food vendors } \\
(\mathbf{n}=\mathbf{1 0 0})\end{array}$} \\
\hline & No & $\%$ \\
\hline $\begin{array}{l}\text { Place of food preparation } \\
\text { At home } \\
\text { At the stall during sales }\end{array}$ & $\begin{array}{l}32 \\
68\end{array}$ & $\begin{array}{l}32.0 \\
68.0\end{array}$ \\
\hline $\begin{array}{l}\text { Type of surface used for preparing street food } \\
\text { Wood } \\
\text { Aluminum } \\
\text { Plastic } \\
\text { Cement/cardboard/newspaper/ Marble }\end{array}$ & $\begin{array}{l}66 \\
17 \\
12 \\
5\end{array}$ & $\begin{array}{c}66.0 \\
17.0 \\
12.0 \\
5.0\end{array}$ \\
\hline Cleanliness of preparation surface (Cooked vegetable, meat, etc.) & \multicolumn{2}{|c|}{$\mathbf{n}=\mathbf{5 0}$} \\
\hline \begin{tabular}{|l} 
Clean \\
Unclean/ Dirty
\end{tabular} & $\begin{array}{l}30 \\
20\end{array}$ & $\begin{array}{l}60.0 \\
40.0\end{array}$ \\
\hline $\begin{array}{l}\text { Chance to touch raw food items with cooked one } \\
\text { Yes } \\
\text { No }\end{array}$ & $\begin{array}{l}20 \\
30\end{array}$ & $\begin{array}{l}40.0 \\
60.0\end{array}$ \\
\hline $\begin{array}{l}\text { Wash food before cooking } \\
\text { Yes } \\
\text { No }\end{array}$ & $\begin{array}{l}35 \\
15\end{array}$ & $\begin{array}{l}70.0 \\
30.0\end{array}$ \\
\hline
\end{tabular}


Table (7): Distribution of the studied sample according to food-handling practices in serving foods.

\begin{tabular}{|c|c|c|}
\hline \multirow[t]{2}{*}{ Items } & \multicolumn{2}{|c|}{$\begin{array}{c}\text { Street food } \\
\text { vendors }(\mathbf{n}=\mathbf{1 0 0}) \\
\end{array}$} \\
\hline & No & $\%$ \\
\hline \multicolumn{3}{|l|}{ Serving food \# } \\
\hline Aluminum plates & 53 & 53.0 \\
\hline News papers & 42 & 42.0 \\
\hline Plastic plates & 40 & 40.0 \\
\hline Plastic bags & 24 & 24.0 \\
\hline Enamel plates & 21 & 21.0 \\
\hline Disposal plates/cups & 7 & 7.0 \\
\hline \multicolumn{3}{|l|}{ Food storage \# } \\
\hline Cooler box / refrigerator & 48 & 48.0 \\
\hline Openly in the stalls & 31 & 31.0 \\
\hline Covered on the wheelbarrows & 25 & 25.0 \\
\hline Plastic container & 14 & 14.0 \\
\hline \multicolumn{3}{|l|}{ Dealing with leftover food\# } \\
\hline Throw away & 48 & 48.0 \\
\hline Re-sale at next day & 25 & 25.0 \\
\hline Take back home & 19 & 19.0 \\
\hline No leftover food & 16 & 16.0 \\
\hline Using oil for frying foods & \multicolumn{2}{|c|}{$(n=100)$} \\
\hline Yes & 30 & 30.0 \\
\hline No & 70 & 70.0 \\
\hline Frequency of change frying oil & \multicolumn{2}{|c|}{$(\mathbf{n}=\mathbf{3 0})$} \\
\hline Monthly & 20 & 66.7 \\
\hline Weekly & 8 & 26.7 \\
\hline Daily & 2 & 6.7 \\
\hline
\end{tabular}

\# Multiple responses were given 
Table (8): Distribution of the studied sample according to hygienic practices during handling of utensils and their total practice scores.

\begin{tabular}{|c|c|c|}
\hline \multirow[t]{2}{*}{ Items } & \multicolumn{2}{|c|}{$\begin{array}{l}\text { Street food vendors } \\
\qquad(\mathrm{n}=100)\end{array}$} \\
\hline & No & $\%$ \\
\hline \multirow{2}{*}{\multicolumn{3}{|c|}{$\begin{array}{l}\text { - Handling of utensils: } \\
\text { Frequency of washing cooking utensils }\end{array}$}} \\
\hline & & \\
\hline Once/day & 78 & 78.0 \\
\hline Twice or more & 18 & 18.0 \\
\hline Occasional & 4 & 4.0 \\
\hline \multicolumn{3}{|l|}{ Place for cleaning utensils } \\
\hline Bucket & 63 & 63.0 \\
\hline Rinse with water & 19 & 19.0 \\
\hline Basin & 18 & 18.0 \\
\hline \multicolumn{3}{|l|}{ Method of washing utensils } \\
\hline Cold water and soap & 53 & 53.0 \\
\hline Hot water and soap & 24 & 24.0 \\
\hline wiping clothlwipe with paper/newspapers & 13 & 13.0 \\
\hline Clean water only & 10 & 10.0 \\
\hline \multicolumn{3}{|l|}{ Frequency of changing washing water } \\
\hline Frequently/When becomes viscous and sticky & 58 & 58.0 \\
\hline Twice daily & 25 & 25.0 \\
\hline Once daily & 17 & 17.0 \\
\hline \multicolumn{3}{|l|}{ Total practice scores } \\
\hline - Poor & 23 & 23.0 \\
\hline - Fair & 67 & 67.0 \\
\hline - Good & 10 & 10.0 \\
\hline Mean \pm SD & \multicolumn{2}{|c|}{$7.9 \pm 1.9$} \\
\hline
\end{tabular}


Table (9): Distribution of the studied sample according to observed personal hygienic practices.

\begin{tabular}{|l||c|c||c|c||}
\hline \multicolumn{1}{|c||}{ Items } & \multicolumn{3}{c||}{ Street food vendors n=100 } \\
\cline { 2 - 5 } & \multicolumn{2}{|c||}{ Yes } & \multicolumn{2}{c||}{ No } \\
\cline { 2 - 5 } & No & $\%$ & No & $\%$ \\
\hline Talking while working with food & 97 & 97.0 & 3 & 3.0 \\
Handling food and money without washing hands in & 93 & 93.0 & 7 & 7.0 \\
between & & & & \\
Dry sweat in a way that does not contaminate food & 90 & 90.0 & 10 & 10.0 \\
Handle foods without gloves & 86 & 86.0 & 14 & 14.0 \\
Use of clean clothes & 77 & 77.0 & 23 & 23.0 \\
Short clean finger nails & 71 & 71.0 & 29 & 29.0 \\
Smoking while working with food & 56 & 56.0 & 55 & 55.0 \\
Clean hands & 56 & 56.0 & 44 & 44.0 \\
Wears jewelry & 42 & 42.0 & 58 & 58.0 \\
Blows air into polythene bag before use & 26 & 26.0 & 74 & 74.0 \\
Wear apron & 20 & 20.0 & 80 & 80.0 \\
Hair covering & 16 & 16.0 & 84 & 84.0 \\
Coughing over food & 14 & 14.0 & 86 & 86.0 \\
Itching in his hair/body while working with food & 12 & 12.0 & 88 & 88.0 \\
\hline \hline
\end{tabular}


Table (10): Distribution of the studied sample according to their knowledge about food safety and total knowledge scores.

\begin{tabular}{|c|c|c|}
\hline \multirow[t]{2}{*}{ Items } & \multicolumn{2}{|c|}{$\begin{array}{c}\begin{array}{c}\text { Street food vendors } \\
(n=100)\end{array} \\
\end{array}$} \\
\hline & No & $\%$ \\
\hline \multicolumn{3}{|l|}{ Types of food borne diseases \# } \\
\hline Food poisoning & 51 & 51.0 \\
\hline Dysentery & 50 & 50.0 \\
\hline Typhoid & 10 & 10.0 \\
\hline Hepatitis A & 7 & 7.0 \\
\hline \multicolumn{3}{|l|}{ Symptoms of food borne illness \# } \\
\hline Stomach pain & 100 & 100 \\
\hline Diarrhea & 55 & 55 \\
\hline Vomiting & 34 & 34 \\
\hline Nausea & 10 & 10 \\
\hline Headache & 10 & 10 \\
\hline \multicolumn{3}{|l|}{ Mode of transmission of food borne diseases \# } \\
\hline Poor hygienic practices & 61 & 61.0 \\
\hline Flies and insects & 42 & 42.0 \\
\hline Insufficient cooking & 14 & 14.0 \\
\hline Preservation of food & 4 & 4.0 \\
\hline Coughing over food & 7 & 7.0 \\
\hline \multicolumn{3}{|l|}{ Sources of food contamination\# } \\
\hline Insects and dirt & 50 & 50 \\
\hline Food coloring/flavoring & 44 & 44 \\
\hline Kerosene oil/detergent & 19 & 19 \\
\hline Worms and parasites & 16 & 16 \\
\hline Invisible germs in foods & 13 & 13 \\
\hline \multicolumn{3}{|l|}{ Causes of food poisoning \# } \\
\hline Contaminated through vector/rodents/insects & 91 & 91.0 \\
\hline Drink unsound water & 14 & 14.0 \\
\hline Handling food with unclean hands & 7 & 7.0 \\
\hline Not keep food at the proper temperature & 6 & 6.0 \\
\hline Don't know & 4 & 4.0 \\
\hline \multicolumn{3}{|l|}{ Sources of knowledge\# } \\
\hline Self-taught/ by experience & 86 & 86.0 \\
\hline Parents & 12 & 12.0 \\
\hline Observation of others & 11 & 11.0 \\
\hline Formal training & 1 & 1.0 \\
\hline \multicolumn{3}{|l|}{ Total knowledge scores } \\
\hline Poor & 92 & 92.0 \\
\hline Satisfactory & 8 & 8.0 \\
\hline Mean \pm SD & \multicolumn{2}{|c|}{$3.7 \pm 1.3$} \\
\hline
\end{tabular}

\# Multiple responses were given 
Table (11): Relation between total knowledge scores of street food vendors and their socio-demographic characteristics.

\begin{tabular}{|c|c|c|c|c|c|}
\hline \multirow{3}{*}{ Characteristics } & \multicolumn{4}{|c|}{ Knowledge $(n=100)$} & \multirow{3}{*}{$M C P$} \\
\hline & \multicolumn{2}{|c|}{$\begin{array}{l}\text { Poor(n=92) } \\
\end{array}$} & \multicolumn{2}{|c|}{ Satisfactory $(\mathrm{n}=8)$} & \\
\hline & No & $\%$ & No & $\%$ & \\
\hline \multicolumn{5}{|l|}{ Age (in years) } & \multirow{5}{*}{0.152} \\
\hline$<20$ & 18 & 19.6 & 0 & 0.0 & \\
\hline $20-$ & 33 & 35.9 & 3 & 37.5 & \\
\hline $30-$ & 25 & 27.1 & 2 & 25 & \\
\hline $40+$ & 16 & 17.4 & 3 & 37.5 & \\
\hline \multicolumn{5}{|l|}{$\overline{\text { Education }}$} & \multirow{6}{*}{0.213} \\
\hline Illiterate $\&$ or read and write & 47 & 51.1 & 3 & 37.5 & \\
\hline Primary education & 5 & 5.4 & 2 & 25 & \\
\hline Preparatory education & 13 & 14.1 & 2 & 25 & \\
\hline Secondary education & 18 & 19.6 & 0 & 0.0 & \\
\hline Above-middle education & 9 & 9.8 & 1 & 12.5 & \\
\hline \multicolumn{5}{|l|}{ Place of residence } & \multirow{3}{*}{0.575} \\
\hline Rural & 48 & 52.2 & 5 & 62.5 & \\
\hline Urban & 44 & 47.8 & 3 & 37.5 & \\
\hline \multicolumn{5}{|l|}{ Duration of being street vendor } & \multirow{5}{*}{0.128} \\
\hline$<5$ years & 54 & 58.7 & 5 & 62.5 & \\
\hline $5-$ & 28 & 30.4 & 1 & 12.5 & \\
\hline $10-$ & 9 & 9.8 & 1 & 12.5 & \\
\hline $20+$ & 1 & 1.1 & 1 & 12.5 & \\
\hline \multicolumn{5}{|l|}{ Types of vendor } & \multirow{3}{*}{0.589} \\
\hline Stationary & 55 & 59.8 & 4 & 50.0 & \\
\hline Mobile & 37 & 40.2 & 4 & 50.0 & \\
\hline
\end{tabular}

MCP: P value based on Mont Carlo exact probabilityP value based on Fisher exact probability 
Table (12): Relation between total practice scores of street food vendors and their sociodemographic characteristics.

\begin{tabular}{|c|c|c|c|c|c|c|c|}
\hline \multirow{3}{*}{ Characteristics } & \multicolumn{6}{|c|}{$\operatorname{Practice}(n=100)$} & \multirow{3}{*}{$M C P$} \\
\hline & \multicolumn{2}{|c|}{$\begin{array}{c}\text { Poor } \\
(n=23)\end{array}$} & \multicolumn{2}{|c|}{ Fair $(n=67)$} & \multicolumn{2}{|c|}{$\begin{array}{c}\text { Good } \\
(\mathrm{n}=\mathbf{1 0}) \\
\end{array}$} & \\
\hline & No & $\%$ & No & $\%$ & No & $\%$ & \\
\hline \multicolumn{8}{|l|}{ Age (in years) } \\
\hline$<20$ & 6 & 26.1 & 11 & 16.4 & 1 & 10.0 & \multirow{4}{*}{$0.035^{*}$} \\
\hline $20-$ & 7 & 30.4 & 27 & 40.3 & 2 & 20.0 & \\
\hline $30-$ & 2 & 8.7 & 22 & 32.8 & 3 & 30.0 & \\
\hline $40+$ & 8 & 34.8 & 7 & 10.5 & 4 & 40.0 & \\
\hline \multicolumn{8}{|l|}{ Education } \\
\hline Illiterate \& or read and write & 12 & 52.2 & 32 & 47.7 & 6 & 60.0 & \multirow{5}{*}{0.076} \\
\hline Primary education & 4 & 17.3 & 2 & 3.0 & 1 & 10.0 & \\
\hline Preparatory education & 4 & 17.3 & 8 & 12.0 & 3 & 30.0 & \\
\hline Secondary education & 1 & 4.4 & 17 & 25.3 & 0 & 0.0 & \\
\hline Above-middle education & 2 & 8.8 & 8 & 12.0 & 0 & 0.0 & \\
\hline \multicolumn{8}{|l|}{ Place of residence } \\
\hline Rural & 19 & 82.6 & 27 & 40.3 & 7 & 70.0 & \multirow[t]{2}{*}{$0.001 *$} \\
\hline Urban & 4 & 17.4 & 40 & 59.7 & 3 & 30.0 & \\
\hline \multicolumn{8}{|l|}{ Duration of being street vendor } \\
\hline$<5$ years & 14 & 60.9 & 41 & 61.2 & 4 & 40.0 & \multirow{4}{*}{0.316} \\
\hline $5-$ & 6 & 26.1 & 20 & 29.8 & 3 & 30.0 & \\
\hline $10-$ & 2 & 8.7 & 6 & 9.0 & 2 & 20.0 & \\
\hline $20+$ & 1 & 4.3 & 0 & 0.0 & 1 & 10.0 & \\
\hline \multicolumn{8}{|l|}{ Types of vendor } \\
\hline Stationary & 6 & 26.1 & 48 & 71.6 & 5 & 50.0 & $0.001 *$ \\
\hline Mobile & 17 & 73.9 & 19 & 28.4 & 5 & 50.0 & \\
\hline
\end{tabular}

MCP: P value based on Mont Carlo exact probability

\footnotetext{
$* \mathrm{P}<0.05$ (significant)
} 
Table (13): Relation between sources of water supply and street food vendors' hygienic practices.

\begin{tabular}{|c|c|c|c|c|c|c|c|c|c|}
\hline \multirow{3}{*}{ Items } & \multicolumn{8}{|c|}{ Sources of water supply } & \multirow{3}{*}{$M C P$} \\
\hline & \multicolumn{2}{|c|}{ Home } & \multicolumn{2}{|c|}{$\begin{array}{l}\text { Private } \\
\text { property }\end{array}$} & \multicolumn{2}{|c|}{ Mosques } & \multicolumn{2}{|c|}{$\begin{array}{l}\text { Public } \\
\text { areas }\end{array}$} & \\
\hline & No & $\%$ & No & $\%$ & No & $\%$ & No & $\%$ & \\
\hline \multicolumn{9}{|l|}{$\begin{array}{l}\text { Cleanliness of preparation surface } \\
(\text { Cooked vegetable, meat, etc. }) \\
(n=50)\end{array}$} & \multirow[t]{3}{*}{$0.050 *$} \\
\hline \multirow{2}{*}{$\begin{array}{l}\text { Clean } \\
\text { Unclean/ Dirty }\end{array}$} & 8 & 16.0 & 5 & 10.0 & 13 & 26.0 & 4 & 8.0 & \\
\hline & 2 & 4.0 & 2 & 4.0 & 8 & 16.0 & 8 & 16.0 & \\
\hline \multicolumn{9}{|l|}{ Washfood before cooking } & \multirow{3}{*}{$0.019 *$} \\
\hline \multirow{2}{*}{$\begin{array}{l}\text { Yes } \\
\text { No }\end{array}$} & 5 & 10.0 & 4 & 8.0 & 17 & 34.0 & 9 & 18.0 & \\
\hline & 9 & 18.0 & 1 & 2.0 & 4 & 8.0 & 1 & 2.0 & \\
\hline \multicolumn{9}{|l|}{$\begin{array}{l}\text { Frequency of washing cooking } \\
\text { utensils }(n=100)\end{array}$} & \multirow{4}{*}{0.766} \\
\hline \multirow{3}{*}{$\begin{array}{l}\text { Once/day } \\
\text { Twice or more } \\
\text { Occasional }\end{array}$} & 21 & 21.0 & 8 & 8.0 & 35 & 35.0 & 14 & 14.0 & \\
\hline & 2 & 2.0 & 2 & 2.0 & 4 & 4.0 & 10 & 10.0 & \\
\hline & 2 & 2.0 & 2 & 2.0 & 0 & 0.0 & 0 & 0.0 & \\
\hline \multicolumn{9}{|l|}{$\begin{array}{l}\text { Frequency of changing washing } \\
\text { water }\end{array}$} & \multirow{4}{*}{0.304} \\
\hline $\begin{array}{l}\text { Frequently/When becomes } \\
\text { viscous and sticky }\end{array}$ & 10 & 10.0 & 3 & 3.0 & 31 & 31.0 & 14 & 14.0 & \\
\hline Twice daily & 5 & 5.0 & 1 & 1.0 & 17 & 17.0 & 2 & 2.0 & \\
\hline Once daily & 0 & 0.0 & 0 & 0.0 & 5 & 5.0 & 12 & 12.0 & \\
\hline \multicolumn{9}{|l|}{ Pealing with waste water } & \multirow{3}{*}{$0.050 *$} \\
\hline Throw on the road surface & 22 & 22.0 & 4 & 4.0 & 29 & 29.0 & 8 & 8.0 & \\
\hline $\begin{array}{l}\text { Throw into the drainage } \\
\text { system }\end{array}$ & 3 & 3.0 & 6 & 6.0 & 18 & 18.0 & 10 & 10.0 & \\
\hline \multicolumn{9}{|l|}{ Total practice scores } & \multirow{4}{*}{0.137} \\
\hline Poor & 11 & 44.0 & 3 & 30.0 & 6 & 12.5 & 3 & 25.0 & \\
\hline Fair & 13 & 52.0 & 6 & 60.0 & 37 & 77.1 & 11 & 58.3 & \\
\hline Good & 1 & 4.0 & 1 & 10.0 & 5 & 10.4 & 3 & 16.7 & \\
\hline
\end{tabular}

MCP: P value based on Mont Carlo exact probability $* \mathrm{P}<0.05$ (significant) 
Table (14): Relation between personal hygienic practices and total knowledge scores of street food vendors.

\begin{tabular}{|c|c|c|c|c|c|}
\hline \multirow{3}{*}{ Items } & \multicolumn{4}{|c|}{ Knowledge $(n=100)$} & \multirow{3}{*}{ FEP } \\
\hline & \multicolumn{2}{|c|}{ Poor $(\mathbf{n}=92)$} & \multicolumn{2}{|c|}{$\begin{array}{c}\text { Satisfactory } \\
(n=8)\end{array}$} & \\
\hline & No & $\%$ & No & $\%$ & \\
\hline Use of clean clothes & 71 & 77.2 & 6 & 75.0 & 0.889 \\
\hline Short clean finger nails & 65 & 70.7 & 6 & 75.0 & 0.795 \\
\hline Clean hands & 81 & 88.0 & 8 & 100.0 & 0.300 \\
\hline Hair covering & 12 & 13.0 & 4 & 50.0 & $\begin{array}{c}0.006 \\
*\end{array}$ \\
\hline Handle foods without gloves & 88 & 95.7 & 8 & 100.0 & 0.547 \\
\hline Talking while working with food & 89 & 96.7 & 8 & 100.0 & 0.604 \\
\hline Dry sweat in a way that does not contaminate food & 36 & 39.1 & 2 & 25.0 & 0.430 \\
\hline Smoking while working with food & 52 & 56.5 & 4 & 50.0 & 0.722 \\
\hline Wears jewelry & 54 & 58.7 & 4 & 50.0 & 0.633 \\
\hline Handling food and money without washing hands in between & 85 & 92.4 & 8 & 100.0 & 0.419 \\
\hline Wear apron & 16 & 17.4 & 4 & 50.0 & $\begin{array}{c}0.027 \\
*\end{array}$ \\
\hline Blows air into polythene bag before use & 25 & 27.2 & 1 & 12.5 & 0.364 \\
\hline Itching in his hair/body while working with food & 21 & 22.8 & 1 & 12.5 & 0.499 \\
\hline Coughing over food & 12 & 13.0 & 2 & 25.0 & 0.350 \\
\hline
\end{tabular}

FEP: $\mathrm{P}$ value based on Fisher exact probability $* \mathrm{P}<0.05$ (significant)

Table (15): Relation between personal hygienic practices and total practice scores of street food vendors.

\begin{tabular}{|c|c|c|c|c|c|c|c|}
\hline \multirow{3}{*}{ Items } & \multicolumn{6}{|c|}{ Practice $(n=100)$} & \multirow{3}{*}{ MCP } \\
\hline & \multicolumn{2}{|c|}{ Poor } & \multicolumn{2}{|c|}{ Fair } & \multicolumn{2}{|c|}{ Good } & \\
\hline & No & $\%$ & No & $\%$ & No & $\%$ & \\
\hline Use of clean clothes & 17 & 73.9 & 52 & 77.6 & 8 & 80.0 & 0.910 \\
\hline Short clean finger nails & 15 & 65.2 & 49 & 73.1 & 7 & 70.0 & 0.769 \\
\hline Clean hands & 19 & 82.6 & 61 & 91.0 & 9 & 90.0 & 0.534 \\
\hline Hair covering & 10 & 43.5 & 5 & 7.5 & 1 & 10.0 & $\begin{array}{c}0.001 \\
*\end{array}$ \\
\hline Handle foods without gloves & 20 & 87.0 & 67 & $\begin{array}{c}100 . \\
0\end{array}$ & 9 & 90.0 & $\begin{array}{c}0.013 \\
*\end{array}$ \\
\hline Talking while working with food & 20 & 87.0 & 67 & $\begin{array}{c}100 . \\
0\end{array}$ & 10 & $\begin{array}{c}100 . \\
0\end{array}$ & $\begin{array}{c}0.006 \\
*\end{array}$ \\
\hline Dry sweat in a way that does not contaminate food & 12 & 52.2 & 20 & 29.9 & 6 & 60.0 & $\begin{array}{c}0.050 \\
*\end{array}$ \\
\hline Smoking while working with food & 11 & 47.8 & 39 & 58.2 & 6 & 60.0 & 0.663 \\
\hline Wears jewelry & 10 & 43.5 & 41 & 61.2 & 7 & 70.0 & 0.239 \\
\hline $\begin{array}{l}\text { Handling food and money without washing hands in } \\
\text { between }\end{array}$ & 19 & 82.6 & 64 & 95.5 & 10 & $\begin{array}{c}100 . \\
0\end{array}$ & 0.073 \\
\hline Wear apron & 6 & 26.1 & 11 & 16.4 & 3 & 30.0 & 0.429 \\
\hline Blows air into polythene bag before use & 9 & 39.1 & 15 & 22.4 & 2 & 20.0 & 0.259 \\
\hline Itching in his hair/body while working with food & 3 & 13.0 & 17 & 25.4 & 2 & 20.0 & 0.462 \\
\hline Coughing over food & 5 & 21.7 & 7 & 10.4 & 2 & 20.0 & 0.341 \\
\hline
\end{tabular}

MCP: P value based on Mont Carlo exact probability $\quad * \mathrm{P}<0.05$ (significant) 


\section{References}

1. Abdalla M, Suliman S, Alian H, Bakhiet O. Food safety knowledge and practices of street food-vendors in Khartoum City. Sud.J.Vet.Sci.Anim.Husb2008; 47.

2. Odu N, Ameweiye B. Microbiological Quality of Street-Vended-Ready-To-Eat "Bole" Fish In Port Harcourt Metropoplis. New York Science Journal 2013; 6 (2).

3. Rane S. Street Vended Food in Developing World: Hazard Analyses. Indian J Microbiol. Jan 2011; 51(1): 100-106.

4. Martins J. Socio-economic and hygiene features of street food vending in Gauteng. SAJCN 2006, 19 (1).

5. World Health Organization. Essential safety requirements for street-vended foods. 1996.

6. FAO/WHO Regional Meeting on Food Safety for the Near East. "Practical Actions to Promote Food Safety". Final report. 5-6 March 2005. Amman, Jordan.

7. Grujić $\mathrm{R}$, Ivanović $\mathrm{M}$, Antonić B.Implementation of food safety management system in food production and handling in Northern Serbia. Quality Of Life 2009; 1(2-4):114-120.

8. Nurudeen A, Lawal O, Ajayi A. A survey of hygiene and sanitary practices of street food vendors in the Central State of Northern Nigeria 2014; 6(5): 174-181.

9. Rahman M, Arif M, Bakar K, \&Tambi Z. Food safety knowledge, attitude and hygiene practices among the street food vendors in Northern Kuching City, Sarawak, Malaysia.Borneo Science 2012; 31.

10. Kasturwar B, ShafeeM. Knowledge, Practices and Prevalence of MRSA among Food Handlers.Int J Biol Med Res. 2011; 2(4): $889-894$.
11. Gadi C, Bala L, Kumar A. Study of Hygienic practices of street food vendors in Allahabad City, India and Determination of Critical control points for safe street food.The Allahabad Farmer 2013; XVIII (2).

12. Muleta D, Ashenafi M. Salmonella, Shigella and growth potential of other food-borne pathogens in Ethiopian street vended foods. East African Medical Journal2001; 78 (II).

13. Jayaprada G. A study to assess the effectiveness of structured teaching programme on knowledge, and practice regarding food hygiene among street vendors in urban areas of Bidar. Dissertation. Community Health Nursing, Akkamahadevi College of Nursing, Bidar, Karnataka State, 2010 - 2011.

14. Choudhury, M, Mahanta L, GoswamiJ, Mazumder $\mathrm{M}$ and Pegoo B. Socioeconomic profile and food safety knowledge and practice of street food vendors in the city of Guwahati, Assam, India. Food Control 2011; 22: 196-203.

15. Johnson $\mathrm{Y}$ and Yawson M. Enhancing the food security of the peri-urban and urban poor through improvements to the quality, safety and economics of street-vended foods. Report on workshop for stakeholders, policy makers and regulators of street-food vending in accra 2000.

16. Adjrah Y, Soncy K, Anani, K, Blewussi K, Karou D, Ameyapoh Y, de Souza C, and Gbeassor M. Socio-economic profile of street food vendors and microbiological quality of ready-to-eat salads in Lomé.International Food Research Journal 2013; 20(1): 65-70.

17. Kitagwa W, Bekker J \&Onyango R. The influence of knowledge, attitudes and practices of food handlers on food kiosk hygiene. Eldoret, Kenya. Environment and Health International 2006; 8(2): 1929. 
18. Ackah T, Gyamfi K, Anim J, Osei K, Hansen O. Socio-Economic Profile, Knowledge of Hygiene and Food Safety Practices among Street-Food Vendors in some parts of Accra-Ghana. Internet Journal of Food Safety 2011; 13:191197.

19. Muinde K, Kuria. Hygienic and sanitary practices of vendors of street foods in Nairobi, Kenya. African Journal of Food Agriculture Nutrition and Development 2005; 5 (1).

20. Hanashiro A, Morita M, Matté R, Matté $\mathrm{H}$ and Torres S. Microbiological quality of selected street foods from a restricted area of Sao Paulo City, Brazil. Food Control 2005; 16: 439-444.

21. Behrens H, Barcellos N, Frewer J, Nunes P, Franco M, Destro T. and Landgraf M. Consumer purchase habits and views on food safety: A Brazilian study. Food Control2010; 21: 963-969.

22. Abdalla M, Suliman S, Alian H, Bakhiet O. Food safety knowledge and practices of street food-vendors in Atbara City (NaherElneel State Sudan). African Journal of Biotechnology2009; 8 (24): 6967-6971.

23. Developing food safety strategies and procedures through reduction of food hazards in street-vended foods to improve food security for consumers, street food vendors and input suppliers. Project final report. 1 February 2003 31 December 2004.
24. Chukuezi C. Food Safety and Hygienic Practices of Street Food Vendors in Owerri, Nigeria. Studies in Sociology of Science 2010; 1 (1): 50-57.

25. Buted D, Ylagan A. Street Food Preparation Practices. Asia Pacific Journal of Education, Arts and Sciences 2014; 1 (2).

26. Reang T, Bhattacharjya H. Knowledge of hand washing and food handling practices of the street food vendors of Agartala, a North Eastern City of India. Journal of Evolution of Medical and Dental Sciences 2013; 2 (43): 83188323.

27. Tauxe R, Quick R, Mintz E. Safer water, cleaner hands, and safer foods: disease prevention strategies that start with clean water at the point of use. Centers for Disease Control and Prevention. National Academy of Sciences 2009.

28. Mensah P, Yeboah-Manu D, OwusuDarko K and Ablordey A. Street foods in Accra, Ghana: how safe are they? Bulletin of the World Health Organization. WHO, Geneva. The International Journal of Public Health 2002; 80 (7): 546-553.

29. deSousa C. The impact of food manufacturing practices on food borne diseases. Braz Arch BiolTechnol2008; 51(4):815-823. 